\title{
Technologia wykonania konstrukcji osłony odzawałowej obudowy kopalnianej Proces spawania elementów obudowy
}

\author{
The technology of making a construction \\ of an anti-breaking down mining support \\ The process of welding elements of the support
}

\section{Streszczenie}

W artykule przedstawiono wymagania dotyczące podgrzewania wstępnego i temperatury warstw pośrednich, uprawnień spawaczy oraz realizacji procesu spawania. Omówiono proces młotkowania i wymagania dla powierzchni lica spoiny. Podano wymagania dotyczące spawania, w tym przeciwdziałania występowaniu pęcherzy, spawania w narożach, wykonywania spoin wielowarstwowych, zakończenia ściegów. Przedstawiono sposoby odprężania konstrukcji oraz warunki prowadzenia napraw wadliwych odcinków spoin.

Słowa kluczowe: spawanie, konstrukcja spawana, plan spawania
Abstract

Requirements referring to the initial heating and the temperature of interpass, welders' authorities and an implementation of a welding process were presented in the following paper. A process of hammering and specifications for the face of weld were given. Welding specifications such as avoiding creation of gas pockets, welding in the corners, making multilayer welds, finishing welding sequences were provided. Stress relieving of a structure and the conditions of mending faulty sections welds were presented.

Keywords: welding, welded construction, welding procedure

\section{Wstęp}

Publikacja stanowi drugą część cyklu prezentującego proces wytwarzania konstrukcji spawanej obudowy górniczej. W poprzedniej części przedstawiono zagadnienia cięcia termicznego detali, ukosowania, montażu i sczepiania oraz kontroli dotyczącej tego zakresu wytwarzania konstrukcji obudowy odzawałowej.

W bieżącej publikacji omówiono zagadnienia dotyczące podgrzewania przed spawaniem, spawania wg Instrukcji Technologicznych Spawania (WPS) i planów spawania, prowadzenia badań nieniszczących oraz w przypadku wykrytych niezgodności wykonywania napraw $[1 \div 19]$.

\section{Zagadnienia ogólne dot. spawania}

\section{Podgrzewanie wstępne}

i temperatura warstw pośrednich

Podgrzewanie wstępne jest istotnym czynnikiem w procesie spawania osłony odzawałowej obudowy kopalnianej. Podstawowym zadaniem podgrzewania $w$ procesie spawania jest zmniejszenie szybkości chłodzenia i zmniejszenie ryzyka występowania procesu hartowania w strefie wpływu ciepła oraz w konsekwencji ograniczenie kruchości i możliwości wytworzenia pęknięć w złączu spawanym. Celem podgrzewania jest również obniżenie naprężeń wynikających z odkształceń wewnętrznych wynikających z odkształceń wywołanych

Dr hab. inż. Jacek Słania, prof. PCz - Politechnika Częstochowska; mgr inż. Henryk Marcinkiewicz, mgr inż. Mariusz Kiełbik - FMG Pioma SA Grupa Famur. 
cyklem spawania oraz stworzenie korzystnych warunków do dyfuzji wodoru ze spoiny. Podgrzewanie wstępne prowadzi się w zależności od:

- gatunku stali,

- grubości elementów,

- rodzaju i rozwiązania konstrukcji spawanej.

Poniżej temperatury $5^{\circ} \mathrm{C}$ należy zawsze stosować podgrzewanie osuszające.

Temperaturę podgrzewania należy sprawdzać termokredkami, pirometrem z celownikiem optycznym lub innym przyrządem w odległości 75 $\div 100 \mathrm{~mm}$ od miejsca, w którym będzie wykonana spoina sczepna. Powierzchnia materiału rodzimego powinna być sucha i mieć temperaturę co najmniej $100^{\circ} \mathrm{C}$ przed rozpoczęciem spawania. Do podgrzewania wstępnego nie wolno stosować palników do cięcia.

Minimalna temperatura warstwy pośredniej nie może spadać poniżej wymaganej minimalnej temperatury podgrzewania wstępnego. Szerokość strefy podgrzanej każdej części powinna być nie mniejsza niż $75 \mathrm{~mm}$ od osi spoiny.

Maksymalna temperatura warstwy pośredniej musi być mierzona na krawędzi rowka i nie może przekraczać wartości podanych w załączonych Instrukcjach Technologicznych Spawania (WPS). Podgrzewanie

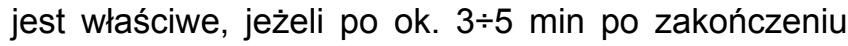
grzania temperatura mieści się w narzuconym zakresie. Przy spawaniu detali z różnych materiałów lub materiałów o różnych grubościach temperaturę podgrzewania wstępnego należy dobrać dla detalu o wymaganej wyższej temperaturze.

\section{Spawacze}

Spawanie mogą wykonywać tylko spawacze i operatorzy sprzętu spawalniczego posiadający aktualne uprawnienia zgodnie z EN 287-1, EN 1418 lub inną, równorzędną normą pod warunkiem zakwalifikowania jej stosowania przez nadzór spawalniczy. Spawacze i operatorzy mogą wykonywać spawanie tylko w zakresie posiadanych uprawnień. Każdy spawacz musi mieć przyznany numer porządkowy lub kod osobisty, pozwalający na identyfikację wykonanych przez niego spoin zarówno w trakcie produkcji, jak i po jej zakończeniu. Każdy spawacz jest zobowiązany do oznaczenia wykonanej przez siebie spoiny przez naniesienie swojego numeru w jej pobliżu. Nadzór spawalniczy zobowiązany jest do przechowywania oraz stałego uaktualniania spisu spawaczy zawierającego zapisy mówiące o zakresach ich upraw-

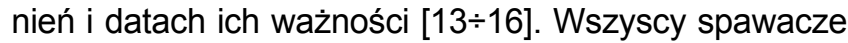
są odpowiedzialni za kontrolę wizualną każdego ściegu po jego czyszczeniu. Kontrola ta związana jest z realizacją procesu spawania i nie zastępuje badań prowadzonych przez pracowników Działu Kontroli Jakości.

\section{Spawanie}

Przed spawaniem miejsca układania spoin należy osuszyć i oczyścić z rdzy, zgorzeliny, olejów itp. Spawanie należy wykonywać zgodnie z załączonymi Instrukcjami Technologicznymi Spawania i etapami spawania, opracowanymi przez nadzór spawalniczy. Nie wolno dopuszczać do powstawania w spoinie kraterów, podtopień, braku przetopu.

Spoiny pachwinowe. Jeśli w dokumentacji konstrukcyjnej nie podano inaczej, to wymiary spoin pachwinowych pokazane na rysunkach należy rozumieć jako wymiary - a. Spoiny pachwinowe wykonywane ręcznie o wymiarach ponad $5 \mathrm{~mm}$ w pozycji nabocznej PB należy wykonywać wielowarstwowo. Warstwy przetopowe należy wykonywać niezwykle starannie, uzyskując pełny, prawidłowy przetop. Warstwy te należy kontrolować, aby stwierdzić, czy nie wystąpiły pęknięcia lub inne wady. Przy wykonywaniu spoin wielowarstwowych należy bardzo starannie oczyścić przez młotkowanie poprzednią warstwę z żużla i odprysków oraz sprawdzić, czy nie występują pęknięcia.

Celem młotkowania igiełkowego (rys. 1) jest czyszczenie międzywarstwowe spoin polegające na usunięciu żużla dla uniknięcia niezgodności - głównie przyklejeń międzywarstwowych. Operację tę należy przeprowadzić w czasie przerw w spawaniu (np. sprawdzenie i utrzymanie temperatury międzyściegowej). Po ostygnięciu spoiny, jeżeli została ona wcześniej przebadana (nie wolno stosować obróbki mechanicznej wcześniej ze względu na zagniatanie niezgodności powierzchniowych), należy również wykonać jej młotkowanie, które łagodzi karby, wygładza powierzchnię, odpręża spoinę oraz usuwa żużel z powierzchni spoiny. Ma to duże znaczenie dla obciążeń zmiennych. Do wykonania operacji młotkowania należy stosować młotek igiełkowy (rys. 1), pneumatyczny z igłami o długości ok.180 mm i średnicy $3 \mathrm{~mm}$. Każda igła musi mieć zaokrągloną końcówkę. Parametry sprężonego powietrza powinny odpowiadać zaleceniom producenta młotka - typowe wartości to 5 barów i $33 \mathrm{l} / \mathrm{min}$. Młotek należy trzymać prostopadle do powierzchni spoiny. Wymagane jest minimum jedno przejście dla każdego brzegu spoiny, a jeśli spoina jest duża, to wymagane są dodatkowe przejścia, tak aby objąć całą jej powierzchnię. Przed rozpoczęciem operacji młotkowania spoinę należy oczyścić ze zgorzeliny. Obrobiona w ten sposób powierzchnia spoiny powinna być jasna, a ślady młotkowania równomierne. Igły podczas młotkowania ulegają zużyciu ściernemu, dlatego też ich stan powinien być regularnie sprawdzany, a końcówki systematycznie szlifowane w celu osiągnięcia zaokrąglenia ich kształtu.

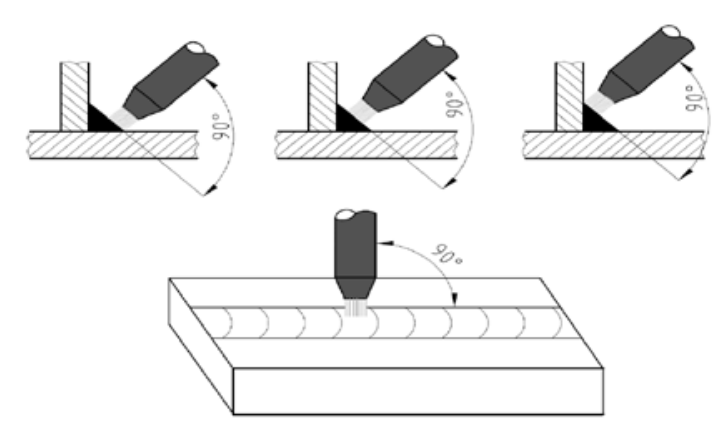

Rys. 1. Proces młotkowania igiełkowego Fig. 1. A process of a needle hammering 
Niedopuszczalne jest układanie kolejnych ściegów spoiny na ściegi, które są pęknięte, przyklejone lub mają pory. Lico spoiny, z wyjątkiem spoin wykonanych w pozycji pionowej, powinno składać się ze ściegów prostych. Przy spoinach czołowych wolne od karbów przejście powinno zostać osiągnięte przez płaskie, łagodnie przechodzące jeden w drugi ściegi kryjące. Należy dążyć, aby maksymalna różnica pomiędzy najwyższym i najniższym punktem lica nie przekraczała $1 \mathrm{~mm}$ (rys. 2).

\section{Łagodne przejście}

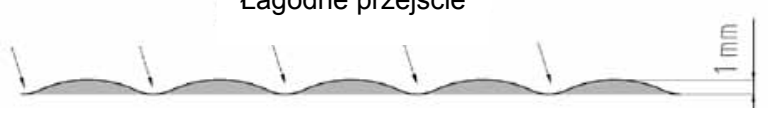

Rys. 2. Przekrój powierzchni lica spoiny

Fig. 2. Surface intersection of a face of weld

Należy przy tym zwrócić szczególną uwagę na wolne od karbów przejścia ściegów kryjących w stosunku do materiału rodzimego.

Przy spoinach czołowych dopuszczalne jest maksymalne przekroczenie grubości i nadlewu spoiny h = $3 \mathrm{~mm}$ (rys. 3). Przy spoinach pachwinowych możliwe jest maksymalne przekroczenie grubości i nadlewu spoiny $\mathrm{h}=2 \mathrm{~mm}$.

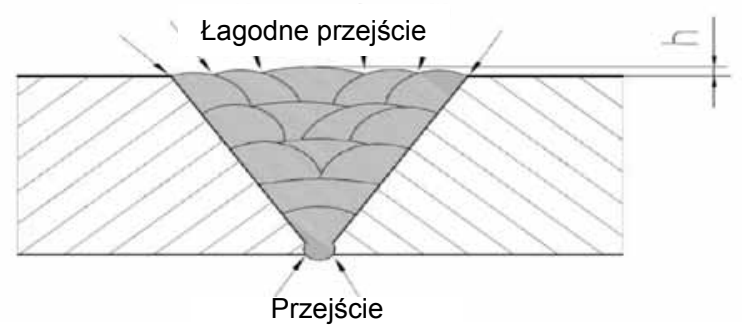

Rys. 3. Przekroczenıe gruboscı I nadlewu spoiny

Fig. 3. Exceeding of a thickness and weld reinforcement

Podczas spawania spoin czołowych uchwyt spawalniczy należy prowadzić tak, aby łuska była ustawiona prostopadle do kierunku spawania z odchyłką do $10^{\circ}$ (rys. 4). Zaleca się, aby przy wykonywaniu spoin czołowych na pełny przetop warstwy przetopowe i licowe (lico bardziej rozlane) stosować spawanie z atakującym ustawieniem palnika (mniejsza głębokość wtopienia), natomiast przy wykonywaniu warstw wypełniających spawać z ciągnącym ustawieniem atakującym palnika (większa głębokość wtopienia).

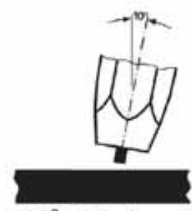

$10^{\circ}$ atakujaco

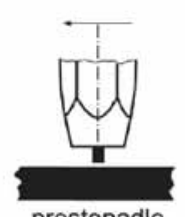
prostopadle

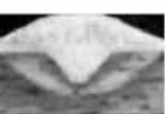

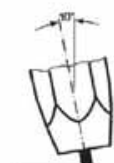

$10^{\circ}$ ciagnąco

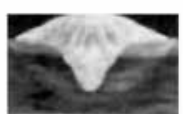

Rys. 4. Wpływ kąta pochylenia drutu elektrodowego na kształt wtopienia [4]

Fig. 4. An influence of an angle of inclination of a welding electrode on a shape of penetration [4]

\section{Zapobieganie powstawaniu pęcherzy gazowych}

Należy pamiętać, że podobnie jak sposób ustawienia palnika, tak również kąt pochylenia palnika (rys. 5), odpowiednia ilość gazu dostarczanego do procesu spawania - czystość otworów wylotowych w palniku (rys. 6) oraz osadzenie się odprysków na wewnętrznej stronie palnika (rys. 7) mają duży wpływ na jakość spoiny.

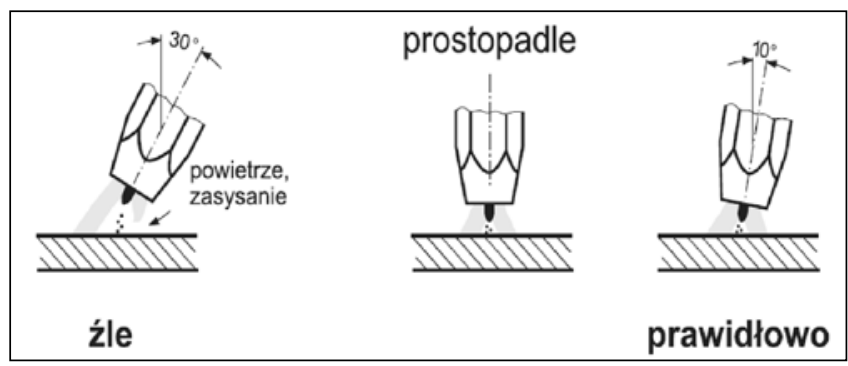

Rys. 5. Powstawanie pęcherzy wskutek złego prowadzenia uchwytu spawalniczego [4]

Fig. 5. Creating gas pockets due to the wrong operation of a welding clamp [4]

\begin{tabular}{|c|c|c|}
\hline (o) & $\begin{array}{l}\text { Wylot gazu zatkany } \\
\text { Nie wolro spryskiwać } \\
\text { preparatem } \\
\text { przeciwodpryskowym } \\
\text { otworów wylotowych } \\
\text { gazu ostonowogo gdyż } \\
\text { możo to spowodowad,, } \\
\text { ze tam będą gromadzić } \\
\text { się odpryski }\end{array}$ & $\begin{array}{l}\text { Wylot gazu wolny } \\
\text { Preparat przeciwodpryskowy } \\
\text { tylko na obrzeżu dyszy } \\
\text { gazowej palnika ogranicza } \\
\text { silne przywieranio odprysków } \\
\text { i ułatwia czyszczenio dyszy, } \\
\text { zapowria to droźnosós } \\
\text { otworów wylotowych gazu }\end{array}$ \\
\hline żle & \multicolumn{2}{|c|}{ prawidłowo } \\
\hline
\end{tabular}

Rys. 6. Powstawanie pęcherzy wskutek zatkania otworów wylotowych gazu w uchwycie [4]

Fig. 6. Creating gas pockets due to blocking gas outlets in the clamp [4]

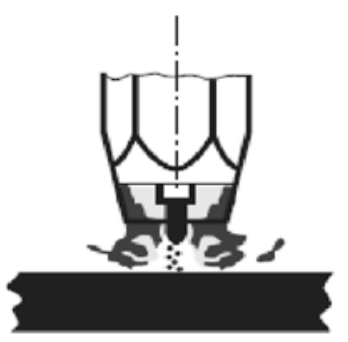

Źle - przepływ ograniczony i turbulentny

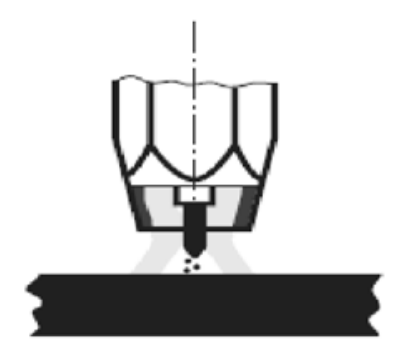

Prawidłowo - przepływ laminarny
Rys. 7. Powstawanie pęcherzy spowodowane osadzeniem się odprysków na wewnętrznej stronie uchwytu spawalniczego [4]

Fig. 7. Creating gas pockets due to placing spalls inside a welding clamp [4]

\section{Technika wykonywania spoin}

Spoiny powinny być jak najdłuższe (mieć jak najmniej przerwań). W przypadku przerwania spawania łuk należy zajarzyć przed końcem spoin $(10 \div 15 \mathrm{~mm})$ i po jego ustabilizowaniu wrócić do krateru, a następnie kontynuować spawanie. Spoiny należy wykonywać możliwie prostymi ściegami, dopuszcza się mały efekt wahadła w zależności od spawanego materiału.

Dopuszczalna szerokość ściegu zakosowego:

- $15 \mathrm{~mm}$ dla stali S235, S355, S420, S460,

- $12 \mathrm{~mm}$ dla stali S620Q, S690Q, S960Q. 
Na rysunku 8 pokazano prawidłowo wykonane lico spoiny czołowej wykonanej ściegami prostymi w pozycji naściennej (PC). Jest ono płaskie, ciągłe (jak najdłuższe, jak najmniej przerw), łączone kaskadowo, łagodnie przechodzące w kolejne ściegi kryjące wolne od karbów takich jak: przyklejenie, pęknięcie, podtopienie i nadmierny nadlew.

Podczas spawania materiałów o różnej wytrzymałości spoiwo należy dobierać do detalu wykonanego z materiału o mniejszej wytrzymałości. Spoina, ani żaden z jej poszczególnych ściegów, nie powinna kończyć się ani zaczynać w narożach konstrukcji.
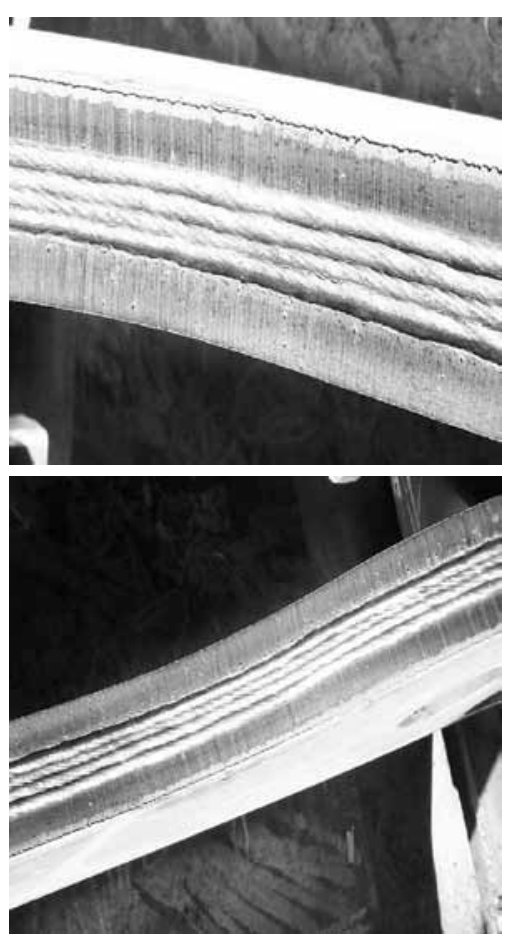

Rys. 8. Prawidłowo wykonane lico spoiny czołowej

Fig. 8. A proper made face of butt weld

\section{Spawanie naroży}

Należy stosować się do zasad spawania pokazanych na poniższych przykładach.

Spawanie naroży - zachowywać sposób układania spoin pokazany na rysunku 9.

W przypadku styku więcej niż dwóch blach, główną spoinę wzdłużną wykonuje się jako ciągłą, chyba że na rysunku wykonawczym zaznaczono inaczej.

Pod żebrami należy wykonywać spoiny ciągłe, które często są spoinami nośnymi (rys. 10). Przerwania ściegów spoiny muszą być założone kaskadowo (np. spoina ściegowa będzie miała założone schodkowo przerwania ściegów na długości $75 \mathrm{~mm}$ ). Ze względu na wytrzymałość zmęczeniową i zjawisko karbu, spoiny nie powinny kończyć się w narożach spawanych blach. Krater końcowy musi być wypełniony i wolny od pęknięć. W miarę możliwości należy „zawinąć” spoinę wokół naroża i zakończyć w minimalnej odległości $25 \mathrm{~mm}$ od naroża (rys. 11) lub należy ją wyprowadzić poza złącze. Jeżeli nie ma takiej możliwości, powstały krater należy tak wypełnić, aby uzyskać żądaną grubość spoiny na całej długości.
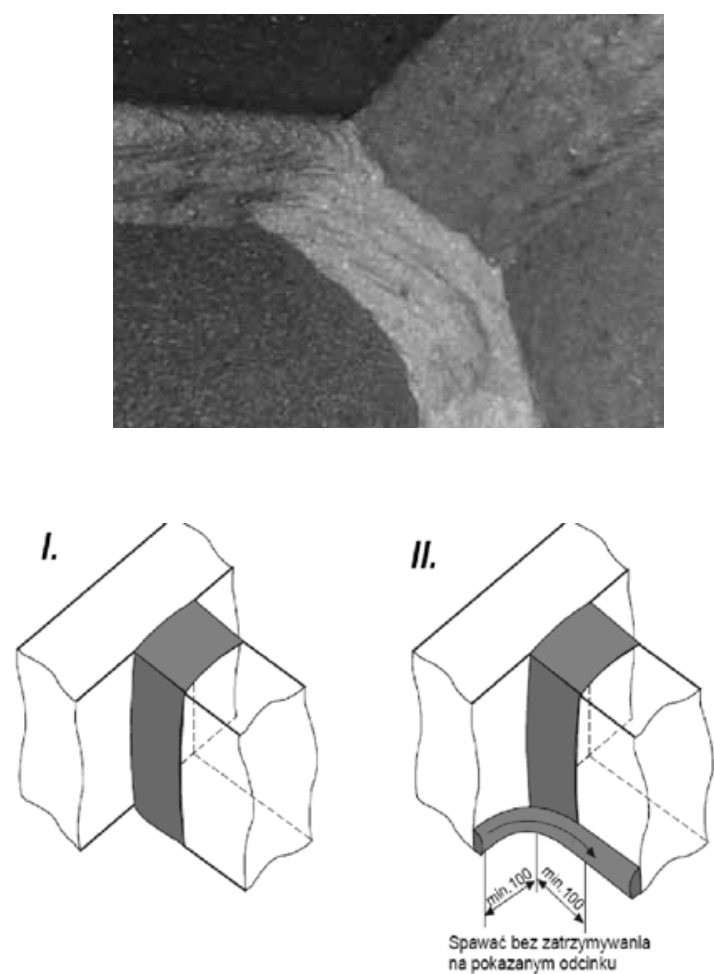

Rys. 9. Kolejność i sposób wykonywania spoin wokół naroża blachy. $\mathrm{Na} z a z n a c z o n y c h$ odcinkach $100 \mathrm{~mm}$ spoiny muszą być ciągłe

Fig. 9. An order and a method of making welds around corner of the metal plates. In the specified sections $100 \mathrm{~mm}$ welds have to be continuous

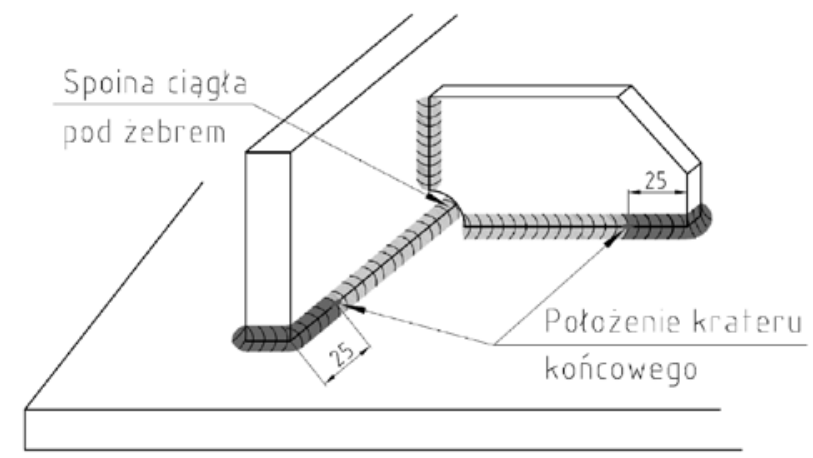

Rys. 10. Prawidłowe miejsce usytuowania krateru

Fig. 10. A proper placement of a crater

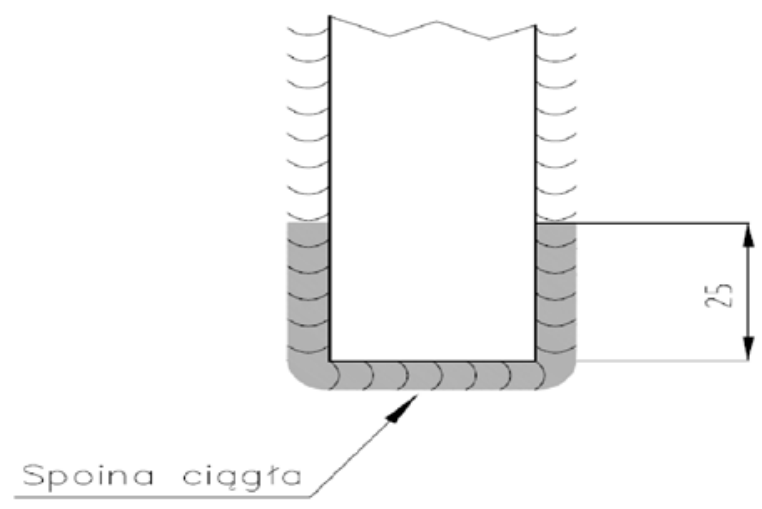

Rys. 11. Sposób wykonywania spoiny wokół naroża blach

Fig. 11. A method of making weld around the corner of metal plates 


\section{Łączenie odcinków spoin wokół przegięć}

W miarę możliwości spoiny wokół przegięć i naroży należy wykonywać jako ciągłe. W tym celu należy tak zaplanować kolejność układania ściegów, aby przerwania były usytuowane poza zabronionym obszarem. W przypadku układania spoiny wieloma ściegami przerwania poszczególnych warstw muszą być założone schodkowo (kaskadowo) na odcinku ok. $75 \mathrm{~mm}$, a w miejscach przegięć i łuków spoiny muszą być ciągłe (rys. 12). Wykonując lico więcej niż jednym ściegiem, należy zwrócić uwagę na to, aby ściegi łagodnie się zlewały.

Należy zwracać szczególną uwagę na to, aby nie było pęknięć w jeziorku spawalniczym, gdzie nastąpito zakończenie spawania. $W$ razie potrzeby krater należy usunąć i ponownie wypełnić. Konstrukcje muszą stygnąć w temperaturze otoczenia, dopóki spoiny nie ostygną do temp. $50^{\circ} \mathrm{C}$ lub niższej.

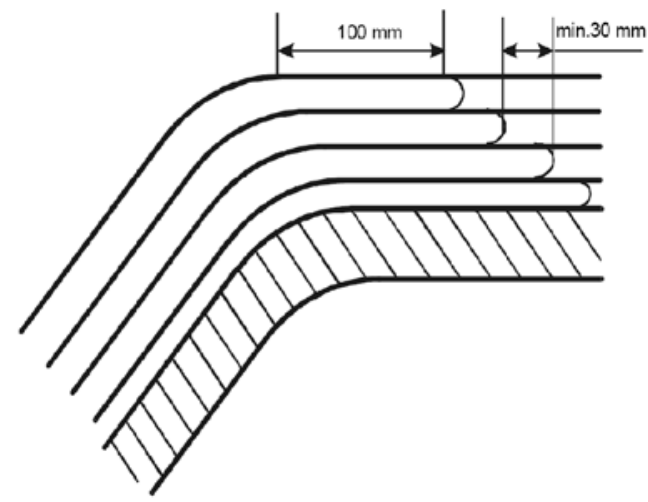

Rys. 12. Łączenie odcinków spoin (3 odcinków)

Fig. 12. Joining sections of welds (3 sections)

\section{Sposób zakończenia spoin}

Koniec spoiny, która będzie połączona ze spoiną wykonaną w kolejnej operacji, powinien być tak wykonany, aby połączenia poszczególnych ściegów nie były skupione $w$ jednym miejscu. W związku z tym końce ściegów wykonywanej spoiny powinny być rozsunięte schodkowo (kaskadowo) na odcinku min. $75 \mathrm{~mm}$ (rys. 13 i 14).

Spoiny wielościegowe należy wykonywać w sposób kaskadowy (schodkowy). Spawanie w formie kaskad należy stosować na mocno usztywnionych elementach, aby uniknąć pęknięć naprężeniowych na stosunkowo słabej warstwie graniowej (rys. 15).

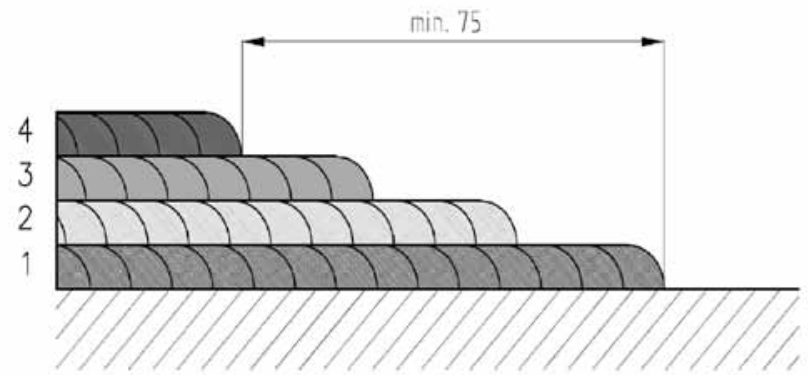

Rys. 13. Sposób zakończenia spoiny, która będzie połączona ze spoiną wykonaną w następnej operacji

Fig. 13. A method of finishing a weld, which will be joined to another weld made in the next process

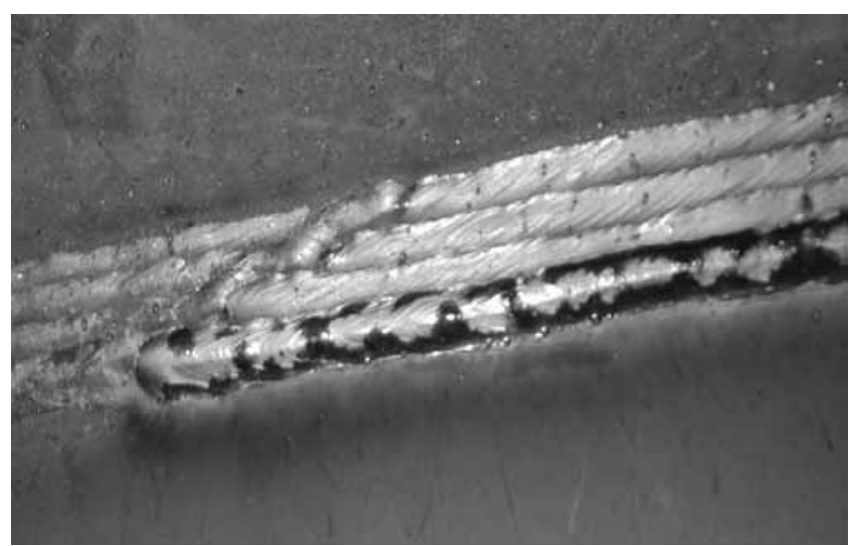

Rys. 14. Kaskadowy sposób połączenia spoiny pachwinowej Fig. 14. A cascade method of joining fillet weld

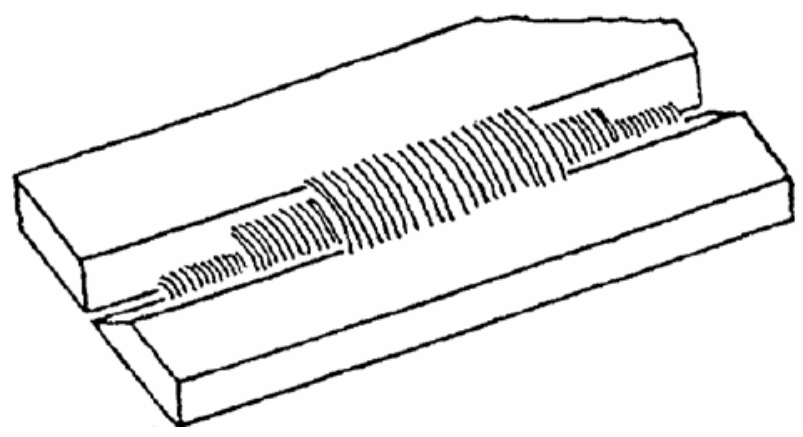

Rys. 15. Sposób wykonywania spoiny wielowarstwowej kaskadowo Fig. 15. A method of making multilayer cascade weld

\section{Zasady wykonywania konstrukcji spawanych}

\section{Zasady ogólne}

Przed przystąpieniem do prac spawalniczych każdorazowo należy zapoznać spawaczy z planami spawania oraz Instrukcją Technologiczną Spawania (WPS), w której jest podany gatunek i średnica drutu elektrodowego, gatunek materiałów dodatkowych, natężenie prądu, kolejność i sposób spawania. Podczas spawania należy bezwzględnie spełniać wszystkie wymagania przewidziane technologią spawania:

- nigdy nie stosować do spawania materiałów spawalniczych niewiadomego pochodzenia i wątpliwej jakości,

- w żadnym przypadku nie spawać elementów nieodpowiednio przygotowanych do spawania, skorodowanych, zatłuszczonych, czy też pokrytych farbą lub lakierem,

- pamiętać o tym, że nadmierna ilość stopionego w spoinie materiału prowadzi do koncentracji naprężeń, nadmiernej deformacji, zwiększenia zużycia drutu oraz czasu spawania i w związku z tym należy dokładnie utrzymywać wymiary spoin podane na rysunkach, 
- pamiętać o tym, że zwiększenie natężenia prądu spawania ponad wielkość przewidzianą w technologii prowadzi do powstania odkształceń konstrukcji spawanej oraz przegrzania materiału rodzimego w strefie wpływu ciepła, a przez to uzyskania złych jakościowo połączeń,

- pamiętać o tym, że odkształcenia konstrukcji spawanej zwiększają się wskutek nieprzestrzegania technologii spawania, tj. naruszenia warunków spawania, niewłaściwego przygotowania i sczepiania elementów do spawania, kolejności układania spoin itp.

Obszerny artykuł na temat planów spawania osłony odzawałowej przedstawiono w [1].

\section{Parametry spawania}

W czasie spawania należy bezwzględnie zachować parametry spawania i uwagi podane w załączonych Instrukcjach Technologicznych Spawania - WPS wykonanych przez nadzór spawalniczy. Odstępstwem od tego może być przypadek, kiedy zleceniodawca uzna, że załączone procedury WPS nie odpowiadają jego standardom. Może wówczas przedstawić własne instrukcje, które zostały przygotowane w oparciu o zatwierdzoną przez niezależny ośrodek certyfikujący procedurę kwalifikowania technologii spawania potwierdzoną przez WPQR wg PN-EN ISO 15614. WPS-y te muszą zostać przygotowane zgodnie z normą PN-EN ISO 15609-1 i zawierać wszystkie niezbędne informacje potrzebne do wykonania prawidłowego złącza spawanego.

$W$ ramach podwykonawstwa lub kooperacji z innymi zakładami na wykonanie konstrukcji spawanych - można zaakceptować procedury przygotowane według innych uznanych norm pod warunkiem, że są w nich spełnione wymagania techniczne. WPS-y takie muszą zostać przed rozpoczęciem produkcji przedstawione do zatwierdzenia.

\section{Odprężanie konstrukcji spawanych}

Konstrukcje spawane w uzgodnieniu z nadzorem spawalniczym w razie potrzeby mogą być poddane odprężaniu przez wyżarzanie odprężające przy zachowaniu następujących parametrów:

- początkowa temperatura pieca powinna wynosić $250 \div 350^{\circ} \mathrm{C}$ - zależnie od złożoności konstrukcji;

- prędkość nagrzewania ok. $60 \div 80^{\circ} \mathrm{C} / \mathrm{h}$, maks $90^{\circ} \mathrm{C}$;

- temperatura wyżarzania wyrobów spawanych powinna zawierać się w granicach $550 \div 650^{\circ} \mathrm{C}$;

- czas wygrzewania powinien wynosić $2 \div 4$ min na $1 \mathrm{~mm}$ grubości najgrubszego elementu, min. $60 \mathrm{~min}$;

- zaleca się szybkość chłodzenia $45 \div 120^{\circ} \mathrm{C} / \mathrm{h}$, zależnie od złożoności wyrobu.

W przypadku wyżarzania odprężającego stali ulepszonych cieplnie lub utwardzonych wydzieleniowo zabieg wyżarzania powinien być przeprowadzony w temperaturze co najmniej $30^{\circ} \mathrm{C}$ niższej od temperatury odpuszczania. Alternatywą wyżarzania odprężającego jest odprężanie wibracyjne [19].

\section{Badania nieniszczące złączy spawanych}

Kontrola nieniszcząca złączy spawanych powinna być przeprowadzona najwcześniej:

- po $24 \mathrm{~h}$ - dla stali niskowęglowych,

- po 48 h - dla stali ulepszanych cieplnie.

Należy zapewnić, aby stygnięcie po spawaniu konstrukcji wykonanych ze stali niskowęglowych przebiegało w warunkach temperatury otoczenia, nie może ono być w żaden sposób przyspieszane, np. przez poddanie nadmuchowi sprężonego powietrza lub działaniu zimnej wody. W przypadku konstrukcji lub elementów wykonanych ze stali ulepszanej cieplnie (stale wymagające podgrzewania przed spawaniem) zaleca się powolne stygnięcie po spawaniu z zastosowaniem dodatkowych środków spowalniających proces stygnięcia, np. za pomocą specjalnych mat, a w przypadku niedużych elementów w pojemnikach z podgrzanym piaskiem.

W przypadku, gdy w dokumentacji konstrukcyjnej lub w warunkach technicznych wykonania i odbioru wyznaczono spoiny do badań ultradźwiękowych, radiograficznych lub magnetyczno-proszkowych, należy je numerować na rysunkach (każdej spoinie przyporządkować oddzielny numer). Na podstawie tak wykonanej numeracji spoin należy sporządzić „Zestawienie spoin” - przykład.

Zakres badań oraz klasa spoin - zgodnie z wytycznymi na rysunkach lub w warunkach technicznych wykonania, muszą być określone w dokumentacji technicznej. Jeżeli brak określenia ww. danych w dokumentacji, należy je uzgodnić z projektantem. Jeżeli projektant nie określi inaczej, badania nieniszczące spoin należy prowadzić wg PN-EN 12062: Badanie nieniszczące złączy spawanych. Zasady ogólne dotyczące metali. Wszystkie spoiny (niezależnie od zaleceń w dokumentacji) należy badać wizualnie (VT) - 100\%. Ponadto należy badać $20 \%$ wszystkich skrzyżowań spoin, zakończeń spoin, łączenia itp.

Styki dodatkowe wynikające z procesu technologicznego, zatwierdzone przez projektanta (konstruktora), należy badać w 100\% metodą wizualną (VT), magnetyczno-proszkową (MT) oraz ultradźwiękową (UT) - metodą UT tylko dla złączy z pełnym przetopem powyżej $8 \mathrm{~mm}$ grubości. Styki te należy również numerować i umieścić w „Zestawieniu spoin”. Badanie spoin przeprowadza pracownik kontroli, a następnie potwierdza ten fakt przez wpis do „Zestawienia spoin” oraz wystawia protokół z badań.

Personel prowadzący badania nieniszczące i ocenę wyników badań do końcowej akceptacji złączy powinien posiadać odpowiednie i aktualne uprawnienia zgodnie z normą PN-EN ISO 9712 Badania nieniszczące. Kwalifikacja personelu badań nieniszczących. Zasady ogólne stopnia 2 w odpowiednim sektorze wyrobu i sektorze przemysłowym.

„Zestawienia spoin” wraz z odpowiadającymi im rysunkami i z narzuconą numeracją spoin oraz protokoły badań stanowią integralną część dokumentacji odbiorowej. 


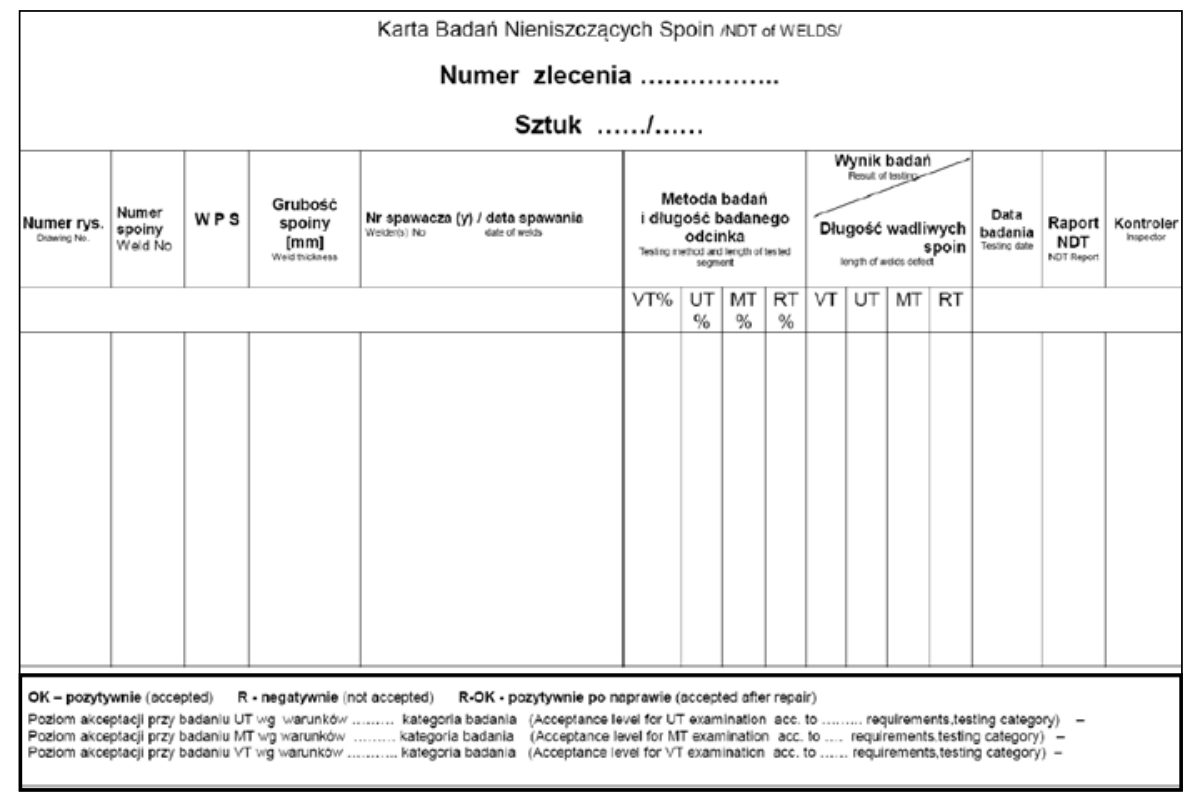

\section{Wykonywanie napraw}

\section{Naprawy niezgodności powierzchniowych przez szlifowanie}

Niezgodności powierzchniowe można naprawiać za pomocą szlifowania pod warunkiem, że nie powoduje to zmniejszenia grubość nominalnej materiału o więcej niż $7 \%$ lub o więcej niż $3 \mathrm{~mm}$, w zależności od tego, która wartość jest większa. Wadliwa powierzchnia ma być oszlifowana na gładko i sprawdzona w 100\% metodą magnetyczno-proszkową (MT).

\section{Naprawy niezgodności powierzchniowych przez spawanie}

Niezgodności o głębokości większej niż 7\% grubości lub $3 \mathrm{~mm}$ muszą być naprawione za pomocą spawania. Wady powierzchniowe takie jak np. wżery, ubytki materiałowe, przypadkowe zajarzenie należy naprawić zgodnie z Kartą Technologiczną Naprawy.

Napawanie naprawcze lub regeneracyjne elementów konstrukcji można prowadzić zgodnie z Kartami Technologicznymi Naprawy wyłącznie za zgodą projektanta.

\section{Naprawa wadliwych spoin}

Przed usunięciem materiału w miejscu wystąpienia niezgodności kontroler wykonujący badanie musi oznaczyć dokładnie na powierzchni metalu miejsce oraz głębokość niezgodności, korzystając, jeśli to konieczne, $z$ dodatkowych technik badań nieniszczących.

Wadliwy materiał musi być usunięty przez obróbkę mechaniczną lub za pomoca żłobienia łukowego, po którym należy wykonać szlifowanie do „zdrowego” metalu. Odcinki spoin zawierające niedopuszczalne niezgodności powinny być naprawiane $\mathrm{z}$ zachowaniem następujących zasad:

- wycięcie niezgodności przez szlifowanie lub żłobienie elektropowietrzne (elektrodą ESM - 257) i szlifowanie, a następnie ponowne spawanie,
- spoiny powinien naprawić spawacz, który je wykonywał,

- dopuszcza się dokonanie poprawek przez innego spawacza posiadającego wymagane uprawnienia. Spawacz ten po wykonaniu poprawek wybija swój znak twardy obok znaku spawacza, który naprawianą spoinę wykonywał,

- obszar naprawy nie może być krótszy niż 50 mm w płaszczyźnie wady wzdłużnej,

- spawanie naprawianych elementów należy przeprowadzić z użyciem takich samych materiałów dodatkowych, jakich użyto do wykonywania spoiny, oraz stosując te same zasady spawania.

Podczas naprawy temperatura wstępnego podgrzewania musi być o $50^{\circ} \mathrm{C}$ wyższa od zastosowanej przed pierwszym spawaniem. Właściwe przygotowanie do naprawy (i jakość spoiny po naprawie) należy potwierdzić przez badanie NDT - 100\% + 100 mm z każdego końca. Dopuszcza się najwyżej dwukrotne poprawianie złączy spawanych (bez pisemnej zgody projektanta), w przypadku wystąpienia dalszych wad należy element spawany wymienić na nowy. Naprawy spoin przez żłobienie oraz naprawy spoin przez ich całkowite wycięcie, ponowne przygotowanie i spawanie należy prowadzić zgodnie z odpowiednią Kartą Technologiczną Naprawy [11].

\section{Magazynowanie materiałów dodatkowych do spawania}

Materiały dodatkowe do spawania muszą mieć odpowiednią jakość. Prawie wszystkie materiały spawalnicze ulegają szkodliwym wpływom wilgoci i dlatego należy je właściwie przechowywać, jak również oznaczać i segregować. Użycie niewłaściwych materiałów dodatkowych do spawania, zwłaszcza do odpowiedzialnych elementów konstrukcyjnych, może mieć poważne następstwa w funkcjonalności wykonanej konstrukcji oraz może mieć wpływ na koszt konstrukcji i czas jej wykonania.

Magazynowanie materiałów dodatkowych do spawania powinno zapewniać ochronę przed zawilgoce- 
niem i uszkodzeniem:

- pomieszczenia magazynowe powinny być zadaszone, suche i wentylowane;

- temperatura otoczenia w magazynie powinna wynosić $\min .+10^{\circ} \mathrm{C}$;

- maks. wilgotność względna w pomieszczeniach magazynowych nie może przekraczać $60 \%$;

- elektrody otulone powinny być składowane na regałach w stosach o wysokości do 0,5 m;

- materiały spawalnicze należy układać na paletach: niedopuszczalne jest układanie elektrod otulonych i drutów spawalniczych bezpośrednio na podłodze;

- magazynowane elektrody otulone i druty spawalnicze powinny być:

- oznakowane pod względem gatunku i wymiarów,

- rozmieszczone na oddzielnych regałach, w zależności od przeznaczenia (oddzielnie niestopowe, średniostopowe, wysokostopowe stalowe, do spawania metali nieżelaznych itd.),

- wydawane sukcesywnie wg kolejnej daty zakupu; - przy magazynowaniu topników (do spawania łukiem krytym) należy przestrzegać następujących zasad:

- obchodzić się ostrożnie z workami, w których pakowany jest topnik, aby ich nie uszkodzić,

- worki przechowywać w suchym miejscu o temp. $10 \div 30^{\circ} \mathrm{C}$,

- nie narażać opakowań topnika (worków) na opady atmosferyczne (deszcz i śnieg);

- przechowywanie gazów spawalniczych powinno odpowiadać przepisom dotyczącym postępowania z gazami technicznymi, w tym przepisom BHP oraz przepisom przeciwpożarowym.

Przed przystąpieniem do spawania należy sprawdzić zgodność rodzaju i gatunku materiałów dodatkowych z wymaganiami podanymi w dokumentacji technologicznej i w Instrukcjach Technologicznych Spawania WPS. Elektrody i druty powinny mieć świadectwo jakości. Należy również sprawdzić ich stan techniczny - nie dopuszcza się stosowania skorodowanych i zanieczyszczonych lub zawilgoconych drutów do spawania.

Nie wolno stosować materiałów dodatkowych o nieokreślonym lub nieczytelnym oznaczeniu gatunku [16].

\section{Wnioski}

Reguły wykonania, kryteria akceptacji itp. zawarte w normach i dokumentach związanych z wyrobem ułatwiają opracowanie dokumentów opisujących standardowe warunki wykonania, które powinny być zapewnione przez wytwórcę. Dla zapewnienia jakości procesów spawania ważna jest ich właściwa kontrola zarówno przed, podczas, jak i po wykonaniu spawania. Jednym z podstawowych dokumentów pomocnych w procesie montażu są karty technologiczne montażu, zaś w procesach spawalniczych poza planami spawania sa to Instrukcje Technologiczne Spawania WPS.

W trzeciej części cyklu publikacji dotyczących technologii wykonania konstrukcji osłony odzawałowej obudowy kopalnianej zostaną omówione zagadnienia kompleksowego spawania obudowy, przedstawione informacje ogólne dotyczące osłony, jej montażu, kontroli wymiarowej oraz podane parametry spawania i szczegóły realizacji badań nieniszczących.

\section{Literatura}

[1] Słania J., Marcinkiewicz H., Kiełbik M.: Plan spawania elementu obudowy kopalnianej - osłony odzawałowej. Przegląd Spawalnictwa, 2012, nr 2, s. 6\%16.

[2] Słania J., Urbańczyk P.: Technologia oraz plan spawania gazoszczelnych ścian rurowych kotła pyłowego wg normy PN - EN 12952-5. Przegląd Spawalnictwa, 2009, nr 12, s. $19 \div 27$.

[3] Słania J.: Technologia spawania płyty wsporczej pojazdu gąsienicowego - dobór parametrów i obliczanie kosztów spawania. Biuletyn Instytutu Spawalnictwa, 2010, nr 2, s. 52 $\div 56$.

[4] Słania J.: Plan technologiczny spawania płyty gąsienicowej. Przegląd Spawalnictwa, 2010, nr 3, s. 16 $\div 25$.

[5] Słania J., Kaczor T.: Plan spawania zbiornika ciśnieniowego.

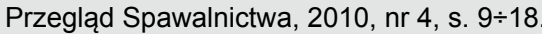

[6] Słania J., Kwiecień L., Jarosiński J.: Plan spawania kotłów płomienicowo-płomieniówkowych. Przegląd Spawalnictwa, 2010 , nr 6, s. $32 \div 40$

[7] Słania J., Skóra J.: Plan spawania wymiennika ciepła chłodzonego powietrzem. Przegląd Spawalnictwa, 2011, nr 2, s. $16 \div 22$.

[8] Słania J.: Plan spawania carg płaszcza pieca obrotowego.

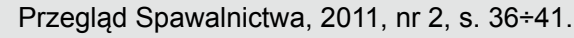

[9] Słania J., Wodecki D.: Plan spawania belki poprzecznej

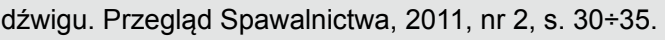

[10] Słania J.: Istota planów spawania. Przegląd Spawalnictwa, 2011 , nr 2, s. $3 \div 9$.

[11] Słania J.: Plan spawania napraw bieżących kotłów parowych, wodnych i stałych zbiorników ciśnieniowych. Przegląd

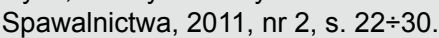

[12] Słania J., Chomiuk S., Dadak R.: Plan spawania dla konstrukcji uzupełniającej - trawersy. Przegląd Spawalnictwa,

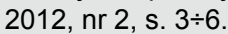

[13] Słania J., Fryc H.: Spawanie pojazdów szynowych - plany spawania. Przegląd Spawalnictwa, 2012, nr 2, s. 16 $\div 20$.

[14] Słania J.: Plan spawania stalowej kładki dla pieszych I. Prze-

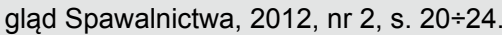

[15] Słania J.: Plan spawania stalowej kładki dla pieszych II.

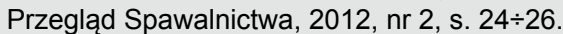

[16] Słania J., Urbańczyk P.: Technologia wytwarzania oraz plan kontroli jakości przegrzewacza pary kotła parowego wg PN-

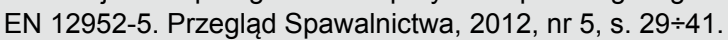

[17] Chromik D., Słania J.: Plan spawania ciśnieniowego zespołu

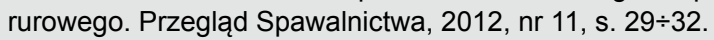

[18] Balcerzak M., Słania J.: Spawanie zbiornika bezciśnieniowego do magazynowania oleju opałowego. Przegląd Spawal-

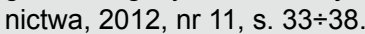

[19] Słania J.: Usuwanie odkształceń spawalniczych. Przegląd

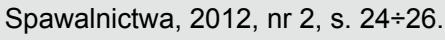

